\title{
Development of Student Worksheet-Based College E-Learning Through Edmodo to Maximize the Results of Learning and Motivation in Economic Mathematics Learning
}

\author{
https://doi.org/10.3991/ijet.v13i12.8636 \\ Anton Nasrullah $\left.{ }^{\bowtie}\right)$, Mira Marlina \\ Universitas Bina Bangsa, Banten, Indonesia \\ anton. nasrullah@binabangsa.ac.id \\ Widya Dwiyanti \\ STKIP Sebelas April Sumedang, Sumedang, Indonesia
}

\begin{abstract}
The objective of the study was to develop a college student worksheet using Edmodo as a learning support tool and to know the effectiveness of peer tutor learning model applied in the learning of economic mathematics on motivation and attitude. Research used for quantitative approach and quasi-experiment method to collect data applying test and questionnaire. The sample in the study is a second-year student enrolled in a college in Serang - Banten. The sample comes from two classes. One class was used for the control group of 29 students; one for the exploratory group of 40 students. In the control group, students were taught only in a personal learning environment using peer tutor models whereas experimental groups studied through peer tutor models in the classroom were supported by student worksheet learning using Edmodo. The findings show that college student worksheet's use is better than traditional learning. That is, students in the experimental group not only outperformed them in the control group in the learning outcomes, but they also showed a higher learning motivation. Although students in both groups did not differ in their attitudes toward peer tutor models, students in the experimental group expressed positive attitudes toward Edmodo. The findings of this study have implications for encouraging educators to see how technology can facilitate as a means of supporting learning and assisting learners resulting in a better atmosphere of economic mathematics learning.
\end{abstract}

Keywords - college student worksheet, motivation, attitude, E-learning

\section{Introduction}

The learning result is the ability of learners is both knowledge (cognitive), attitudes (effective), or skills (psychomotor) obtained through the learning process [1]. Several studies have shown that learners at various levels of education in Indonesia still have low learning outcomes mathematical $[2,3,4]$. Various studies have made efforts to 
improve learning outcomes by using a variety of learning methods eg Reciprocal Teaching [5, 6, 7], Think-Pair-Share [8,9.10], Snowball Throwing [11,12,13]. NCTM states that the presentation of the material for example technology using computer-assisted learning is a vital component to support communications in math because it can be a reference material the students in discussing ideas related to mathematics [14]. This will encourage the learning outcomes student. The statement indicates that in addition to the use of approach to teaching methods that have been done in a variety of research, technological approach can also be used as a means of supporting the learning so that the learning process may facilitate the activities of the learning process of learners effectively and efficiently both in the classroom and outside the classroom (online) leading to achieving optimal learning results.

One technology that has been used in mathematics, for example, the use Edmodo app. Edmodo is a computer application that has been shown to have important benefits in the learning process $[15,16,17,18,19]$. The benefits derived from the use Edmodo among other applications can improve the literacy skills of mathematics and students can receive pedagogy in learning mathematics and students also feel the increased involvement in classroom discourse through Edmodo app [16], increasing the positive attitude of students towards learning [20,21] and increase motivation to learn [22]. Unfortunately, the benefits of using Edmodo has not been applied specifically to improve results and motivation to learn where studies have used the software application help in improving the ability of learning outcomes is [23,24,25] using Moodle software should be: a) requires a better understanding of the system; b) The need for experts to build a system of e-learning; c) cost more; 4) require special hardware compared Edmodo.

Mathematics, students do not just memorize theories and formulas, but more directed in the process of knowledge and mastery of mathematical concepts [28]. The learning process is a process of communication between faculty and students. However, the problem is how to keep the communication process can be delivered effectively and efficiently so that the message conveyed can be received in full by learners [26]. For this purpose, lecturers need to use the media and supporting tools in mathematics. One media that can be used is a College student worksheet [27]. College student worksheet lists of materials, concepts, and understanding that will be constructed student through the problems given. However, the problems found was the limited time in the classroom. Because of time limitations in the use of technology in the classroom through Edmodo app that transforms college student worksheet form (print) into a college student worksheet (online) so as to facilitate faculty in delivering matter from anywhere and anytime.

Results of research on the use of technology in learning show that adaptive learning Utilize technologies that interest may be a powerful way to support learners in gaining fluency with abstract representational systems and based interventions can promote robust learning outcomes [28]. The use of technology can also facilitate student learning in improving understanding of mathematics subject matter [29]. Learning models built using technology can create learning habits and independence [30]. It can be developed by creating a learning environment that encourages students to interact with teachers and classmates with the approach of peer tutors both in the classroom and 
outside the classroom (online). The creation of a pleasant atmosphere and interwoven interactions between students with learning activity is one of the features of the use Edmodo, and various studies show that there is an improvement in the level of involvement of students learning to use Edmodo [31,32,33,34,35,36]. These facts show that Edmodo has the potential to improve student results. One way to develop mathematical thinking ability of students is to familiarize the student to do it continuously [37]. In this study, the continuity of which is in the classroom and outside the classroom (online) managed through Edmodo as a tool to support the learning of mathematics given to students so that they can drive results and motivation to learn them. Therefore, this study investigated the use of college student worksheet based elearning through Edmodo to maximize results and motivation to learn.

\section{Overview}

\subsection{College Student Worksheet}

Easy teaching materials developed by educators is printed form, one of which is a teaching material in the form of college student worksheet. College student worksheet is the source and media that can help students learn in a focused [38] and worksheets focused procedural [39]. In connection with the Student worksheet with technology tools are not only limited in print form but, now developed in non-print form (online). Student non-print worksheet encourages students/students to use it outside the classroom via the Internet [40].

Process more efficient. For example, the time in the classroom is usually discharged to the delivery of the material so that the limited time for exercise. The use of college student worksheet through Edmodo to use computers to address the deficiencies found in the learning process is limited time for face to face and do the exercises. Based on previous research, the learning process using Edmodo shows that in general the students give a positive attitude to learning Edmodo and can save time in the effectiveness of communication [20]. The use Edmodo many challenges and has a great potential for learning [21] and computer-assisted assessment.

\subsection{Peer Tutoring}

There are three tutor models in the following study groups; 1) Student to tutor ie tutor give explanation to all learners with learners ask to tutor; 2) Group to tutor ie tutor gives explanation to group or group that has been formed, and number of tutors adjusted with number of groups; 3) Student to student Information or explanation is not only obtained from the tutor alone but can also from other friends who already understand and understand with the explanation of the tutor [41].

Five steps in the tutor: (a) The tutor asks a question; (b) student answers; (c) the tutor provides feedback on answers; (d) students and tutors collaborate to improve the quality of the answers; and (e) the tutor judges the student to understand the answer [42]. It aims for task management in student worksheets including the introduction and framing 
of problems and can solve them. Approaches using their tutors are given the opportunity to engage in intellectually stimulating classroom discussions and deep learning [43].

Based on the description above about the tutor model, the research model used in organizing the learning process is by peer tutoring method (a group to tutor). Peer tutor approach is a learning method that provides an opportunity for all learners to be able to understand the concept of mathematics evenly, as well as to improve the learning motivation of learners, one of the learning methods is a peer tutor. Tutors usually adapt to learners based on learners' performance characteristics, and learners typically use tutors through classroom (traditional) interface [44] and online. Students who are considered less in learning in the classroom can be more attention by the tutor in each group so that students are not expected to feel reluctant and embarrassed in asking the tutor is about the material that has not understood.

\subsection{Motivation in Learning}

One can encourage student/students motivated in learning environments and student progress online worksheet is the motivation to learn. Motivation to learn is learning driver to become active and multimedia learning environment using computers can improve emotion, motivation, and positive understanding [46]. It is the impact of the use of computers to provide learning resources at any time and used in lieu of or in addition to the more traditional learning resources, such as lectures and textbooks [46].

Motivation is the deciding factor in the extent to which students can achieve the desired learning outcomes [47]. Learning to become effective when an individual is ready to learn, or in other words, when someone wants to know something without coercion or extrinsic rewards [48]. Motivation to learn will not be formed if the students do not have the desire, aspiration and realize the benefits of learning for themselvesalone [49]. Motivation has an important role in influencing the achievement of learners [50].

Learners interact with both students and communication with students, lecturers and students online, it is because there is a boost student motivation to learn. Learning environment using computers and mobile online is attracting students to obtain knowledge and motivation to learn them $[51,52,53]$. Previous research reveals the learning approaches on motivation to learn that learning is more active and can increase the motivation to learn in comparison with conventional learning approaches $[54,55,56]$.

The use of student worksheets through Edmodo app with peer tutors approach can be useful and add confidence to maximize learning outcomes and student learning motivation. Learning in the classroom may not be enough time in the delivery of materials and exercises through Edmodo app, especially for those who have limited understanding of mathematics is low. Therefore, the focus of research is in order to complete the knowledge and student worksheet through Edmodo applications as a means of supporting learning outside the classroom.

Peer tutor learning approach through Edmodo application is designed based on learning objectives, so it can help students in solving problems both in class and out of 
class (online). It is expected to improve student's learning outcomes and motivation to the maximal maximum.

The results of this study will show the effectiveness of the use of student worksheets through Edmodo as a means of supporting learning with the support of technology with in the online learning environment. This leads to learning outcomes and learning motivation in mathematics for the better and will be the design of learning in the syllabus in the future. Based on the literature review, the research focused on three variables: learning outcome, learning motivation, and attitude. Therefore, the use of college student worksheets based on E-learning through Edmodo is enhanced to maximize learning outcomes, motivation and improve positive attitudes toward mathematics learning.

\section{$2.4 \quad$ Research Objectives}

1. To develop a worksheet for a college student in mathematics applied economics.

2. To evaluate the effectiveness of peer tutoring learning approaches

(a) To compare student results experimental class and control class after treatment.

(b) To compare the motivation to learn between the experimental class and control class.

(c) to compare the students' attitude towards the approach of peer tutoring between the experimental class and control.

(d) to measure attitudes toward the use of college student worksheet-based e-learning through Edmodo in the experimental class.

\subsection{Hypothesis}

H1: Students experiment class education outcomes better than the control class.

$\mathrm{H} 2$ : Students in the experimental group had a higher motivation than the control class. H3: Students in the experimental group had a more positive attitude than the control class.

\section{$3 \quad$ Methodology}

\subsection{Participants}

The research was conducted at private university Bina Bangsa University which has 1365 students. The code of economics-mathematics course is MA 16208 (3 SKS) in semester 1 academic year 2017/2018. The fact that this study was conducted at a university made it difficult to scramble every course and allocate it to the control and experimental group. An appropriate choice is to use a qualitative approach with the quasiexperiment method of design used is non-equivalent control group [57]. Consideration of certain factors that may lead to a damaged experiment [58]. In the research process, it does not create a new class group but an existing class group is then selected to determine the experimental class and the control class that has almost the same characteristics. The sample comes from two classes. One class was used for the control group of 
29 students; one for the experimental group of 40 students. Economics mathematics courses last for 14 weeks in one semester with each classroom meeting once a week for 150 minutes.

\subsection{Research design}

The quasi-experimental study was designed to compare the results of learning, motivation, and attitudes among students in mathematics learning economy. In the control group, students are only taught in a face to face learning environment using a model of peer tutors while the experimental group studied through the model of peer tutors in the classroom with the supporting tools online college student worksheet using Edmodo. Both groups started with studies in the setting-face for seven weeks when there are treatments applied to them. Most of the time spent on the content of textbooks. During the week of 9-14, students in the experimental group were given access college student learning and online via Edmodo worksheet used to support after learning in the classroom (face to face), while students in the control group were involved with only a face to face learning in the classroom.

\subsection{Instrument}

The instruments used in the study were three sets of test results and two sets of questionnaires for motivation and attitude. The first instrument is a test used to assess student learning outcomes in experimental and control classes. Pre-test (first test) is done in week 8 and post-test (second test) at week 16 in experiment class and control class. The second instrument in this study was a questionnaire of student motivation in the experimental class and control class of 10 statements [55,60]. Questionnaire Motivation there are 10 items using scale five $(1=$ strongly disagree, $2=$ disagree, $3=$ disagree or disagree, 4 = agree, and 5 = strongly agree).

The third instrument in the study was the questionnaire of student attitudes toward learning using tutorsebaya approach (experimental class and control class) containing 10 items and the use of college student worksheet based on e-learning through Edmodo on economic math learning (experimental class) containing 15 items. Measurement of attitude ie; the degree of student assessment of a statement is divided into 5 (five) categories arranged in stages $[55,60]$. For a statement to support a positive attitude, the score given starting from SS (Strongly Agree) $=5, \mathrm{~S}($ Agree $)=4, \mathrm{~N}($ Neutral $)=3$, TS $($ Disagree $)=2$, STS (Strongly Disagree $)=1$, and for a statement that supports a negative attitude, the score given starting from SS (Strongly Agree) $=1, \mathrm{~S}$ (Agree) $=2$, Neutral $(\mathrm{N})=3$, TS $($ Disagree $)=4$, STS $($ Very Disagree $)=5$. The range is interpreted as follows: $1.00-1.80=$ very negative, $1.81-2.60=$ negative, $2.61-3.40=$ moderate, $3.41-4.20=$ positive, $4.21-5.00=$ very positive.

\subsection{Validity and reliability instruments}

Instruments (a set of learning outcomes and two sets of questionnaires for motivation and attitudes) are used through content validity by means of the Index of items objective 
congruence (IOC) with five experts. The result of the instrument (test and questionnaire (learning motivation and attitude) show that all items can be used because it has the right index between (0.66-1.00). In order to determine internal consistency reliability given to 37 students in another class with Guttman split-half coefficient and/or Cronbach's Alpha coefficient value. The test instrument results show that the Guttman split-half coefficient value is 0.943 (having the high-reliability category). The result of the motivational instrument indicates that Cronbach's Alpha value is 0.768 (has highreliability category). student toward the study of economic mathematics using peer tutoring approach indicates that the alpha coefficient value of 0.772 (has a highreliability category). Students attitude toward the use of college student worksheet based e-learning through Edmodo on learning economic mathematics indicates that the value of the alpha coefficient of 0.756 (category of high reliability).

\subsection{Data analysis}

Data obtained from the test of learning outcomes and motivational questionnaires, attitudes in the learning of economic mathematics were analyzed qualitatively. The pretest is given before treatment and to ensure that the experimental class and control class have a homogeneous equality with an independent t-test. This is also done to determine the learning outcomes between the experimental class and the control class before any treatment. When statistical differences from the pre-test scores between the two classes were found then, the ANCOVA test was used to determine whether the experimental group acquired a higher ability than the control group. Next is to use ANCOVA test used to compare motivation and attitude toward peer tutoring learning approach between experiment class and control class. In addition, the mean and standard deviations are used to indicate motivation, attitudes toward tutoring learning approaches, and attitudes toward using e-learning college student worksheets through Edmodo in all items.

\subsection{College student worksheet model from the experimental group}

The experimental group, after learning through the "Peer Tutor Model" they have the same opportunity to do some activities online learning environment, but, in contrast to the conventional classroom with online learning environment is not given. This study is based on the theory of social media platforms for educators and learners whose function is to share ideas, files, agenda and college student worksheet assignment [61].

The experimental class accepts mathematics learning using peer tutoring approach plus collage student worksheet online through Edmodo (Figure 1).

In conclusion, in the learning activities using Edmodo application is as follows:

1. Prior to learning activities through Edmodo app, lecturer provides guidance on how to use Edmodo application, after it was granted the class code and set an example in its use. Then enroll students according to the example and the stages in the guide. When they understand in use, they can operate it by means of post-sentence in the comments field. Activities in Edmodo students have started to communicate both among students and students and students with faculty. 


\section{Face-to-face meeting (Peer Tutoring)}

Discuss in small groups an explanation from tutors who already understand and understand

The tutor gives an explanation to group or group which has been established, and the number of tutors adjusted to the number of groups

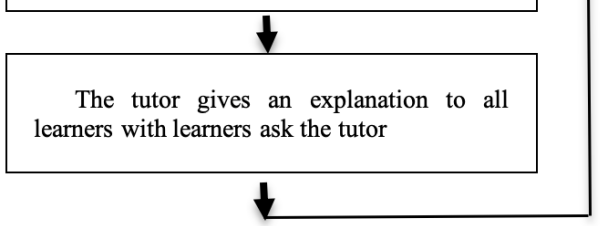

Meeting in Edmodo System (Peer Tutoring)

Students watch the learning clips and how to use them using Edmodo and college student worksheets

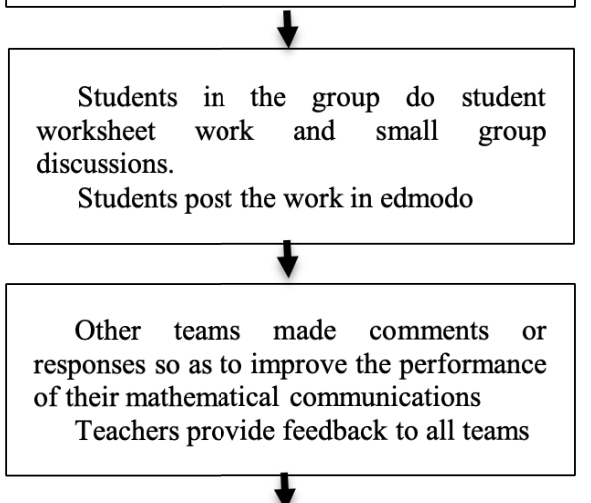

Students who use a single topic and student worksheet posted by the instructor

Students conduct individual student worksheet exercises individually or in groups before conducting discussions and tests.

Fig. 1. Peer tutoring using college student worksheet-based e-learning via Edmodo (modified [55])

2. Forming groups according to predetermined. Within each group, there are tutors who have good academic ability.

3. The lecturer gives a material explanation and example of the problem in the outline. Lecturers provide training to each group in the form of college student worksheet. Training in college student worksheets is discussed with each group. There is limited time for explanation, training, and recording in the classroom, learning is made in elearning based Edmodo application with the material (PDF, Word, Vidio Clip, discussion column) and college student worksheet did online so that it can be done outside the classroom.

4. Forms of college student worksheet there are two forms: first, for exercises discussed with students with tutors, students with students, and students with lecturers; secondly, for individual tests to improve students' ability after learning and training. This is done to measure the learning ability of each student. Form the test in the form of multiple choice and essay. 


\section{$4 \quad$ Findings}

Research Question 1: To what extent is the use of the effectiveness of college student worksheet based on e-learning on learning economic mathematics through Edmodo can improve student learning outcomes?

Table 1. Score pre-test and post-test.

\begin{tabular}{|l|c|c|c|c|c|c|c|}
\hline \multirow{2}{*}{ Kelas } & \multirow{2}{*}{$\mathbf{p}$} & \multicolumn{3}{c|}{ Pre-Test } & \multicolumn{3}{c|}{ Post-Test } \\
\cline { 3 - 7 } & & $\overline{\boldsymbol{x}}$ & $\boldsymbol{s}$ & $\boldsymbol{t}$ & $\overline{\boldsymbol{x}}$ & $\boldsymbol{s}$ & $\boldsymbol{t}$ \\
\hline Experiment (n=40) & 0.027 & 23.0 & 11.6 & \multirow{2}{*}{-2.56} & 76.8 & 5.5 & \multirow{2}{*}{3.56} \\
\hline Control (n=29) & 0.16 & 30.1 & 14.4 & & 71.4 & 7.2 & \\
\hline
\end{tabular}

After a statistical test is obtained in Table 1 to show descriptive statistics of the results before and after the tests for both groups. The results of the pre-test obtained the score of the students in the control group and the experimental group 30.1 and 23.0 out of 100 points, and those scores increased to 71.4 and 76.8 respectively after receiving treatment. The result of the pre-test score shows that the control group is higher than the experimental group $(30.1,23.0)$.

The pre-test results were analyzed using the t-test to compare the values of their initial mathematical abilities before treatment. This is done to ensure that samples from both groups are the same since the pre-test. The pre-test results show that $\mathrm{t}=-2.56$, df $=67$, and $\mathrm{Sig}=0.027$, indicating that the groups are not significant. This shows that compared to post-test analyzed using ANCOVA, using pre-test score as covariance.

The first research hypothesis aims to determine whether the learning outcomes of the experimental class students is higher than the control class after treatment. The results showed that the students in the experimental group had better learning outcomes than the control group after treatment $(\bar{x}=76.8,71.4)$ (Table 1).

To test the hypothesis, the mean value of post-test tests of both groups was compared with ANCOVA. The results of the analysis show that the experimental group learning outcomes are significantly higher than the control group $(F=12.64, \mathrm{Sig}=.001)($ Table 2). Thus, Hypothesis 1 is accepted which states that the students in the experimental group have better learning outcomes than the control group.

Research college student worksheet and supported e-learning environment through Edmodo have great benefits as a supporting tool for learning mathematics. This is a good platform for students to learn and share knowledge so as to enhance the motivation of a positive attitude toward learning [55].

Table 2. ANCOVA post-test results classroom experiment and control.

\begin{tabular}{|l|c|c|c|c|}
\hline \multicolumn{1}{|c|}{ Source } & df & MS & F & Sig \\
\hline Corrected Model & 1 & 496.82 & 12.64 & .001 \\
\hline Intercept & 1 & 369555 & 9400 & .000 \\
\hline Group & 1 & 496.82 & 12.64 & .001 \\
\hline Error & 67 & 39.315 & & \\
\hline Total & 69 & & & \\
\hline Corrected Total & 68 & & & \\
\hline
\end{tabular}


Each student has different skills in both experimental and control classes with learning using peer tutor approach, offering opportunities for those with low learning ability to learn from the advice of better-off tutor members either directly in the classroom or outside the classroom with the application Edmodo. In addition, students have more opportunities to watch clips of discussion provided in Edmodo that can be seen by each class. They not only learn what other teams do, they also have to express their thoughts.

The learning process can provide a personal response to Edmodo can support the social aspects of learning. That is, communication both face to face directly or indirectly (online) Because Edmodo is an innovative tool in teaching and learning process based on cognitive style [62]. The time in the classroom usually runs out for the delivery of materials with limited time to practice.

In this study, the activity of learning process of economic mathematics with peer tutor approach using communication technology support tools such as Edmodo has the possibility that students can learn and practice outside the classroom can create an innovative learning environment that enables better and efficient in improving learning outcomes better by completing certain tasks with new context and situation. The effectiveness of the learning model using Edmodo is similar to that of previous studies which found that it can have a positive impact on learning [21, 55, 62,].

Research Question 2: Are the students' experimental class motivations different from the control class?

At the end of the lesson, a motivational questionnaire was given to both groups of both experimental and control classes to assess their motivation. Based on Table 3, the experimental group students have more motivation than those in the control group in eight items including numbers $1,2,3,6$, and 10 . There are two items (no 4, no 5 and no 7) students in the control group had more motivation than those in the experimental group.

When considering each item, it was found that the highest average grade of the experimental group on item no. 6 (The content of this lesson is useful to me, $\bar{x}=4.38$ ) and the control group on item no. 5 (I feel confident that I will do well in this lesson, $\bar{x}=4.38)$.

Table 3. The average results of motivation score

\begin{tabular}{|c|l|c|c|c|c|}
\hline \multirow{2}{*}{ No. Motivation } & \multicolumn{2}{c|}{ Control } & \multicolumn{2}{c|}{ Experiment } \\
\cline { 3 - 6 } & & $\overline{\boldsymbol{X}}$ & $\boldsymbol{S D}$ & $\overline{\boldsymbol{x}}$ & $\boldsymbol{S D}$ \\
\hline 1. & I enjoy studying economic mathematics. & 3.62 & 0.728 & 4.15 & 0.802 \\
\hline 2. & I actively participate in this learning activity & 3.9 & 0.939 & 4.08 & 0.859 \\
\hline 3. & I think the tasks are given are not too difficult & 3.07 & 0.842 & 3.87 & 0.883 \\
\hline 4. & I am very satisfied with this lesson & 4.24 & 0.636 & 4.15 & 0.921 \\
\hline 5. & I feel confident that I will do well in this lesson & 4.31 & 0.806 & 4.12 & 0.939 \\
\hline 6. & The content of this lesson is useful to me & 3.69 & 1.137 & 4.38 & 0.74 \\
\hline 7. & Content in this course motivates me to learn & 4.21 & 0.902 & 4.1 & 0.778 \\
\hline 8. & This learning activity captured my attention & 4.03 & 0.778 & 4.18 & 0.781 \\
\hline 9. & This learning can develop my math skills & 4.17 & 0.711 & 4.22 & 0.698 \\
\hline 10. & The number of tasks and jobs in this lesson are appropriate & 3.76 & 1.091 & 4.02 & 0.947 \\
\hline & & $\mathbf{3 . 9}$ & $\mathbf{0 . 8 6}$ & $\mathbf{4 . 1 3}$ & $\mathbf{0 . 8 3}$ \\
\hline
\end{tabular}


Research Question 3: What is the student's attitude towards peer tutor peer learning approaches in experimental and control classes?

After getting the lessons, the students were given an attitude survey towards peer tutor. Based on Table 4 the overall attitude of the scores of the two groups is not much different. Both groups have a positive attitude toward the peer-peer tutor model $(\bar{x}=$ $3.90,4.04)$. However, when considering each item, the students in the experimental group stated a more positive attitude toward the tutor's model than the control group in five items $(3,4,7,8$, and 9).

Table 4. The average outcome of attitude score.

\begin{tabular}{|c|c|c|c|c|c|}
\hline \multirow{2}{*}{ No } & \multirow{2}{*}{ Attitudes to the Peer Tutor Approach } & \multicolumn{2}{|c|}{ Control } & \multicolumn{2}{|c|}{ Experiment } \\
\hline & & $\bar{x}$ & $S D$ & $\bar{x}$ & $S D$ \\
\hline 1. & $\begin{array}{l}\text { Through peer tutor approach, I was encouraged to be able to } \\
\text { speak and interact with economic math learning. }\end{array}$ & 4.1 & 0.778 & 4.2 & 0.758 \\
\hline 2. & $\begin{array}{l}\text { Peer tutor approach is a good way to study economic mathe- } \\
\text { matics. }\end{array}$ & 4 & 0.784 & 4.3 & 0.687 \\
\hline 3. & I think the peer tutor approach does not take time & 4.13 & 0.686 & 3.8 & 0.687 \\
\hline 4. & I feel comfortable when lecturers use peer tutor approach. & 4.1 & 0.841 & 4.02 & 0.891 \\
\hline 5. & Peer tutor approach helped me expose ideas more smoothly. & 3.85 & 0.921 & 3.9 & 0.81 \\
\hline 6. & $\begin{array}{l}\text { I become more active when learning through peer tutor ap- } \\
\text { proach. }\end{array}$ & 4.02 & 0.891 & 4.13 & 0.883 \\
\hline 7. & $\begin{array}{l}\text { I am more confident communicating mathematically through } \\
\text { peer tutor approach. }\end{array}$ & 4.15 & 0.58 & 3.82 & 0.903 \\
\hline 8. & $\begin{array}{l}\text { Peer tutor approach allowed me to study systematic eco- } \\
\text { nomic mathematics. }\end{array}$ & 4.25 & 0.84 & 3.9 & 0.744 \\
\hline 9. & $\begin{array}{l}\text { Peer tutor approach helped me improve my ability to speak } \\
\text { mathematically. }\end{array}$ & 4.2 & 0.758 & 3.88 & 0.723 \\
\hline 10. & $\begin{array}{l}\text { Peer tutor approach makes me more accurate in my college } \\
\text { student worksheet }\end{array}$ & 3.77 & 0.92 & 3.83 & 0.781 \\
\hline & Mean & 4.06 & 0.79 & 3.98 & 0.79 \\
\hline
\end{tabular}

Group of control class students, the highest average score is in item no. 8 (Peer tutor approach allows me to study economic mathematics systematically, $\bar{x}=4.25$ ), item no. 9 (Peer tutor approach helped me improve my ability to speak mathematically, $\bar{x}=4.2$ and item No. 7 (I am more confident communicating mathematically through peer tutor approach, $\bar{x}=4.15$ ) The lowest average grade of class attitudes control is item No. 10 (Peer tutor approach makes me more accurate in doing college student worksheet, $\bar{x}=$ 3.77).

The experimental class group, the highest mean score falls on item no. 2 (Peer tutor approach is a good way to study economic mathematics, $\bar{x}=4.3$ ), item no. 1 (Through peer tutor approach, I was encouraged to be able to speak and interact with economic math learning, $\bar{x}=4.2$ ), item no. 6 (I become more active when learning through tutor's model, $\bar{x}=4.13$ ). The lowest score average is item no. 3 (I think peer tutor approach does not take time). 
Results from the ANCOVA analysis (Table 5) revealed that there was a difference in motivation between the experimental and control groups. That is, the motivation of the experimental group students was significantly higher than the control group at the 0.05 significance level $(\mathrm{F}=14.797, \mathrm{Sig}=0.000)$. Therefore, the hypothesis states that students who learn through peer tutor models supported with college student worksheets gain higher motivation than those who receive only face-to-face arrangements are accepted.

Table 5. ANCOVA results student motivation on peer tutor approach.

\begin{tabular}{|l|c|c|c|c|}
\hline \multicolumn{1}{|c|}{ Source } & df & MS & F & Sig \\
\hline Corrected Model & 1 & 87.0105 & 14.797 & .000 \\
\hline Intercept & 1 & 108335.2 & 18423.6 & .000 \\
\hline Group & 1 & 87.011 & 14.797 & .000 \\
\hline Error & 67 & 5.880 & & \\
\hline Total & 69 & & & \\
\hline Corrected Total & $\mathbf{6 8}$ & & & \\
\hline
\end{tabular}

However, the ANCOVA analysis (Table 6) attitudes toward the peer tutor model of the experimental group were not statistically higher than that of the control group $(\mathrm{F}=$ $1.700, \mathrm{Sig}=0.197)$. As a result, the hypothesis states that attitudes toward the peer tutor model of the experimental group are more positive than the control group rejected.

Table 6. ANCOVA result of student's attitudes toward peer tutor approach.

\begin{tabular}{|l|c|c|c|c|}
\hline \multicolumn{1}{|c|}{ Source } & df & MS & F & Sig \\
\hline Corrected Model & 1 & 11.063 & 1.7 & .197 \\
\hline Intercept & 1 & 108567.991 & 1.683 .3 & .000 \\
\hline Group & 1 & 11.063 & 1.7 & .197 \\
\hline Error & 67 & 6.508 & & \\
\hline Total & 69 & & & \\
\hline Corrected Total & $\mathbf{6 8}$ & & & \\
\hline
\end{tabular}

Research Question 4: What is the student's attitude toward learning using a college student worksheet through Edmodo?

Based on Table 7, the overall average score indicates that students have a positive attitude towards learning using college student worksheet through Edmodo $(\bar{x}=3.90)$. The highest average attitudinal value falls on item no. 6 (Edmodo gave me the opportunity to share my duties with my lecturer and colleagues, $\bar{x}=4.25)$, on item no. 10 (Edmodo promotes a collaborative learning environment, $\bar{x}=4.05$ ) and on item no. 5 (I can easily access the class material and college student worksheet work via Edmodo, $\bar{x}=4.00$ ). The lowest average score of the questionnaire is the item no.11 (Edmodo improves self-study skills, $\bar{x}=3.72$ ). It is interesting to see that students express a positive attitude towards Edmodo's use in all items. 
Table 7. ANCOVA results form student attitudes toward peer tutor approach.

\begin{tabular}{|c|l|c|c|}
\hline No. & \multicolumn{1}{|c|}{ Attitude towards college student worksheet Through Edmodo } & $\bar{x}$ & SD \\
\hline 1. & Edmodo allows me to contact my faculty and colleagues outside the classroom. & 3.98 & 0.77 \\
\hline 2. & Edmodo is convenient to use in learning. & 3.85 & 0.66 \\
\hline 3. & I feel comfortable while interacting online through Edmodo. & 3.75 & 0.67 \\
\hline 4. & $\begin{array}{l}\text { Edmodo saves time by doing and sending college student worksheet work elec- } \\
\text { tronically. }\end{array}$ & 3.82 & 0.98 \\
\hline 5. & $\begin{array}{l}\text { I can easily access class material and college student worksheet works through } \\
\text { Edmodo. }\end{array}$ & 4 & 0.82 \\
\hline 6. & $\begin{array}{l}\text { Edmodo gave me the opportunity to share my duties with my Lecturer and col- } \\
\text { leagues. }\end{array}$ & 4.25 & 0.67 \\
\hline 7. & $\begin{array}{l}\text { I can improve learning outcomes using a college student worksheet based on e- } \\
\text { learning through an audio file uploaded in Edmodo. }\end{array}$ & 3.85 & 0.89 \\
\hline 8. & Edmodo facilitates small group discussions (peer tutor approach). & 3.85 & 0.66 \\
\hline 9. & Edmodo increased my motivation to study economic mathematics. & 3.98 & 0.66 \\
\hline 10. & Edmodo promotes a collaborative learning environment. & 4.05 & 0.75 \\
\hline 11. & Edmodo improves self-study skills. & 3.72 & 0.64 \\
\hline 12. & Edmodo allowed me to get feedback from the Lecturer. & 3.82 & 0.75 \\
\hline 13. & Edmodo helped improve my speaking ability mathematically. & 3.82 & 0.39 \\
\hline 14. & $\begin{array}{l}\text { Edmodo helps get problem-solving in economic mathematics through online peer } \\
\text { tutor discussions }\end{array}$ & 3.9 & 0.63 \\
\hline 15 & $\begin{array}{l}\text { Edmodo helped improve my calculations in economic mathematics learning } \\
\text { through the approach of peer tutors (small groups). }\end{array}$ & 3.93 & 0.69 \\
\hline & & $\mathbf{3 . 9 0}$ & $\mathbf{0 . 7 1}$ \\
\hline
\end{tabular}

The range is interpreted as follows: $1.00-1.80=$ very negative, $1.81-2.60=$ negative, $2.61-3.40=$ quite negative, the range is interpreted as follows: $1.00-1.80=$ very negative, $1.81-2.60=$ negative, $2.61-3.40=$ quite negative, $3.41-4.20=$ positive, $4.21-5.00=$ very positive.

3.41- $4.20=$ positive, $4.21-5.00=$ very positive. Adaptation of [25]

\section{Discussion}

The results of the survey conducted in the study revealed that the attitude of studying students who use college student worksheet and supported e-learning environment through Edmodo in the aspect of economic mathematics learning positively positive attitude (Table 6). This is Because First Edmodo is practical; the use of simple but effective when in the class lack of time in carrying out exercises so that it can exercise and discussion, Both Edmodo applications can be used with computers and smartphones done online, Third Edmodo; can improve the effectiveness of learning saves time. Fourth using Edmodo; Students can also share content, submit homework, assignments, and quizzes, receive their feedback instructors, notes.

They realize that Edmodo really helps to improve learning outcomes because of the effectiveness of Edmodo media as a learning support tool that can be done outside the classroom online. Learning using Edmodo can learn actively and motivate learners to gain an effective learning process [63]. Students become more active when they are assigned to perform some activities in an online learning environment and Edmodo is 
a private social network that provides a secure learning platform for learners and educators [61].

Online students can be more likely to learn and practice from professors, peers and even others. The findings were found to be similar to previous studies that analyzed the Edmodo user experience positively and found that satisfaction levels were positively related to the academic outcomes acquired, and negative with perceived benefits in terms of their impact on value [64]. The results of research using college student worksheet and supported e-learning environment through Edmodo in the aspect of economic mathematics learning more effectively and efficiently. This is in accordance with the 21 st-century skills education process because the learning process can be done from anywhere and anytime by utilizing the surrounding environment and technology that is a computer, smartphone, wifi and laboratory as supporting tool of learning.

The findings of this positive attitude are similar to many previous studies $[21,55,65]$ stating that students can be involved in an organized way of learning by using Edmodo through the guidance and guidance of lecturers and assisted by colleagues of students in understanding learning materials and practicing as well as online discussions can be done outside the classroom but the findings of the shortcomings is that Edmodo is not widely used to interact directly with Line, WhatsApp and so on both with lecturers and colleagues outside the classroom. The findings of the lack of use of college student worksheets through Edmodo is the level of internet connection in each student area is different so that it can lead to submit automatically when the task is not finished yet.

\section{Conclusion}

Learning using college student worksheets through Edmodo as a learning support tool to support economic mathematics learning that allows students to be actively involved both in class and out of class so that the impact on student learning outcomes are; memorize, grasp, applying, analyze, evaluate, create.

The tutoring approach by using peer tutoring can encourage a collaborative learning environment where students are encouraged to communicate, practice and work on college student worksheets with peers and lecturers. Based on the results of research is an effective way to achieve better learning outcomes by utilizing the environment around campus and students who can encourage learning activities both in the classroom and outside the classroom (online).

The use of college student worksheets through Edmodo as a means of supporting learning by using technology will of course provide more collective knowledge and web-based applications on tasks outside the classroom that will benefit students and lecturers as an innovative effort in the process of learning to teach economic mathematics because it can be done from where anytime and anytime and recapitulate the value automatically with computer-assisted and smartphone.

Edmodo is a social media platform for educators and learners to share ideas, files, agendas, and assignments in the form of a college student worksheet. The results of research using college student worksheet through Edmodo showed the positive attitude and high acceptance level (strong criterion) by students. Research cannot be separated 
from a number of limitations. The first is that while students work and conduct college student worksheets through Edmodo that can be done outside the classroom but the attitude scale scores suggest that students' attitude responses in the use of learning are higher than their attitudes toward the questions they get. Both of these are not widely used for direct interaction such as Line, WhatsApp, and others both with lecturers and colleagues outside the classroom. The other three limitations are an internet connection in every student area is different. Despite the limitations of the study, the results of this study reveal that the learning of economic mathematics by using college student worksheet based on e-learning through Edmodo is better than conventional learning on student learning outcomes.

\section{$7 \quad$ Acknowledgment}

The researcher would like to thank the Departement Mathematic Education of Bina Bangsa University and Departement Riset and Teknology for giving financial support.

\section{References}

[1] M. Y. Mappeasse, "Influence of Ways and Motivation Learning to Learning Results Programmable Logic Controller (PLC) Students Class III Electrical Department SMK Negeri 5 Makassar," Jurnal Medtek., vol. 1, no.2, pp. 1-6, 2010.

[2] E. Soviawati, "Realistic Mathematics Approach (PMR) to Improve Student Thinking Ability in Primary School Level," Journal of Mathematics Educa-tion., vol. Edisi Khus, no. 2, pp. 154-163, 2011.

[3] N. Elida, "Improving Mathematical Communication Skills of Junior High School Students through Learning Think-Talk-Write (TTW)," Journal of In-finity., vol. 1, no. 2, pp.178-185., 2012.

[4] H. Z. Ramlah, Dani Firmansyah, "Influence of Learning Styles and Activity of Students to Mathematics Learning Achievement," Journal of Scientific Solutions., vol. 1, no. 3, pp. 68$75,2014$.

[5] N. Efendi, "Approach Teaching Reciprocal Teaching Potential Increase Completeness of Biology Learning Results High School Students," Peda-gogia., vol. 2, no. 1, pp. 84-97, 2013.

[6] Z. W. M. Warouw, "Learning Reciprocal Teaching and Metacognitive (RTM) Empowering Learning Outcomes of Biology of Junior High School Students," Journal of Education Sciences., vol. 17, no. 2, pp. 162-171, 2010.

[7] L. Salminda., R. Ramses and Y. Efendi, "Influence of Reciprocal Teaching Model Using Pocket Book on Student Learning Results of Grade VII of MTs Sagulung Batam," SIMBIOSA., vol. 4, no.1, p.35-41, 2015.

[8] N. Azizah, "Cooperative Learning Model Think Pair Share for Student Ac-tivity and Learning Outcomes," Journal of Extraordinary Education., vol. 4 no. 1, pp. 1-16, 2008.

[9] A. Fatmawati, "The Effect of Co-operative Learning on Think Pair Share (TPS) and Creativity Toward Classroom Student Science Outcomes V SD Gugus V," GaneÇ Swara., vol. 5, no. 2, pp. 39-44, 2011.

[10] A. Rahayu, and J.A. Pramukantoro, "The Influence of Think-Pair-Share Learning Model with Index Card Match Strategy on Student Learning Re-sults on Competency Standards 
Applying Elementary Electronics in SMK Negeri 1 Madiun", Journal of Electrical Engineering Education., 2(3), pp.991-999. 2013.

[11] M. Rasyid, and S. Side, "The Influence of Application of Snowball Throw-ing Learning to Classroom Students' Learning Outcomes X SMAN I Bajeng District Gowa," Chemica, 12(2)., pp.69-76, 2013.

[12] V. Daniati., Y. Yuliasma, and Z. Iriani, "Improvement of Student Learning Outcomes with Snowball Throwing Cooperative Model on Dance Class VIIIC Teaching in Junior High School Negeri 1 Bukit Tinggi," SENDRATASIK UNP., vol. 2, no. 1, pp.37-43, 2013.

[13] T. Handayani., M. Mujasam., S.W. Widyaningsih, and I. Yusuf, I," Appli-cation of cooperative learning model of snowball throwing type to learners learning result," Journal of Curricula., vol. 2, no.1, pp.47-58, 2017.

[14] The National Council of Teachers of Mathematics (NCTM), Principles and Standard for Schools Mathematics. Reston, VA: The National Council of Teachers of Mathematics, Inc, 2000.

[15] D.G. Krutka., D.J. Bergman., R. Flores., K. Mason, and A.R. Jack, "Mi-croblogging about teaching: Nurturing participatory cultures through collabo-rative online reflection with preservice teachers," Teaching and Teacher Ed-ucation., 40, pp.83-93, 2014. https://doi.org/10.1016/j.tate.2014.02.002

[16] G.K. Wong, "Engaging students using their own mobile devices for learning mathematics in classroom discourse: A case study in Hong Kong," Interna-tional Journal of Mobile Learning and Organisation, vol. 8, no. 2, pp.143-165, 2014. https://doi.org/10.1504/ IJMLO.2014.062352

[17] T. Trust, "Deconstructing an online community of practice: teachers' actions in the edmodo math subject community," Journal of Digital Learning in Teacher Education., vol. 31, no.2, pp.73-81, 2015 https://doi.org/10.1080/21532974.2015.1011293

[18] S.B. Waluya, and S. Mariani, "Mathematics Literacy on Problem Based Learning with Indonesian Realistic Mathematics Education Approach Assist-ed E-Learning Edmodo," Journal of Physics: Conference Series., vol. 693, no. 1, p. 012014). IOP Publishing. 2016.

[19] I.M. Ardana., I.P.W. Ariawan, and D.G.H. Divayana, "Development of de-cision support system to selection of the blended learning platforms for mathematics and ICT learning at SMK TI Udayana," Development., vol. 5, no.12. pp. 15-18, 2016.

[20] K. M. Al-Said, "Students' perceptions of edmodo and mobile learning and their real barriers towards them," Turkish Online J. Educ. Technol., vol. 14, no. 2, pp. 167-180, 2015.

[21] F. Al-kathiri, "Beyond the Classroom Walls? Edmodo in Saudi Secondary School EFL Instruction, Attitudes and Challenges," English Language Teaching., vol. 8, no. 1, pp.189-204 2015.

[22] R. Novitayati, "The Effect of Blended Learning and Self Regulated Learning Methods on Cognitive Learning Outcomes IPS," Journal of Educational Research., vol. 23, no.1, pp.4857, 2013.

[23] C. Costa., H. Alvelos, and L. Teixeira, "The use of Moodle e-learning plat-form: a study in a Portuguese University," Procedia Technology, 5, pp.334-343, 2012. https://doi.org/10.1016/j.protcy.2012.09.037

[24] C. Romero., P.G. Espejo., A. Zafra., J.R. Romero, and S. Ventura, "Web usage mining for predicting final marks of students that use Moodle cours-es," Computer Applications in Engineering Education., vol. 21, no.1, pp.135-146, 2013. https://doi.org/10.1002/cae.20456

[25] L. Deng and N.J. Tavares, "From Moodle to Facebook: Exploring students' motivation and experiences in online communities," Computers \& Educa-tion., 68, pp.167-176, 2013. https://doi.org/10.1016/j.compedu.2013.04.028 
Paper-Development of Student Worksheet-Based College E-Learning Through Edmodo to Maximize ..

[26] W. Sanjaya, Planning and Design of Learning System. Jakarta: Kencana Prenada Group, 2013.

[27] A. Perdana., S. Siswoyo, and S. Sunaryo, "Development of Discovery Learning Based Student Worksheets PhET Interactive Simulations on New-ton's Legal Material," Wahana Pendidikan Fisika., vol. 2, no.1, pp.73-79, 2017.

[28] C.A. Walkington, "Using adaptive learning technologies to personalize in-struction to student interests: The impact of relevant contexts on performance and learning outcomes," Journal of Educational Psychology., vol. 105, no.4, p.932, 2013. https://doi.org/10.1037/ a0031882

[29] S. H. Anwariningsih and S. Ernawati, "Development of Interactive Media for ICT Learning at Elementary School Based on Student Self Learning," J. Educ. Learn., vol. 7, no. 2, pp. 121-128, 2013. https://doi.org/10.11591/edulearn.v7i2.226

[30] F. Saadati, R. A. Tarmizi, and A. F. M. Ayub, "Utilization of Information and Communication Technologies in Mathematics Learning," Indones. Math. Soc. J. Math. Educ., vol. 5, no. 2, pp. 138-147, 2014. https://doi.org/10.22342/jme.5.2.1498.138-147

[31] C. Holland, and L. Muilenburg, "Supporting student collaboration: Edmodo in the classroom," Society for Information Technology \& Teacher Education International Conference, Association for the Advancement of Computing in Education (AACE), pp. 3232-3236), 2011.

[32] T. Trust, "Professional learning networks designed for teacher learning," Journal of Digital Learning in Teacher Education., vol. 28, no.4, pp.133-138, 2012. https://doi.org/10.1080/ 21532974.2012.10784693

[33] A. Wallace, "Social learning platforms and the flipped classroom," In e-Learning and eTechnologies in Education (ICEEE) Second International Conference on (pp. 198-200). IEEE, 2013. https://doi.org/10.1109/ICeLeTE.2013.6644373

[34] K. Balasubramanian., V. Jaykumar, and L.N. Fukey, "A study on Student preference towards the use of Edmodo as a learning platform to create re-sponsible learning environment," Procedia-Social and Behavioral Sciences, 144, pp.416-422, 2014. https://doi.org/10.1016/ j.sbspro.2014.07.311

[35] B.B. Shams-Abadi., S.D. Ahmadi, and A.G Mehrdad, "The Effect of Ed-modo on EFL Learners? Writing Performance," International Journal of Educational Investigations, vol. 2, no2, pp.88-97, 2015.

[36] C. Greenhow, and E. Askari, "Learning and teaching with social network sites: A decade of research in K-12 related education," Education and Infor-mation Technologies., vol.22 no.2, pp.623-645, 2017. https://doi.org/10.1007/s10639-015-9446-9

[37] K. Kostos and E, "Using math journal to enhance second graders' communi-cation of mathematical thinking," Early Childhood Education Journal, 38, pp. 223-231, 2010. https://doi.org/10.1007/s10643-010-0390-4

[38] D. Rufaida, L. Sudarmin and A. Widiyatmoko. (2013). "Development of Microsoft Expression Web-assisted IPA LKS". Unnes Science Education Journal (USEJ), vol. 2, no.1, pp. 209-216, 2013.

[39] T. J. Gurl., R. Fox., N. Dabovic., \& A. E. Leavitt, "Planning Questions and Persevering in the Practices". National Council of Teachers of Mathe-matics, The Mathematics Teacher, vol. 110, no.1, pp.33-39, 2016.

[40] H. Nishizawa., K. Kimura., W. Ohno., \& T. Yoshioka., "Interactive work-sheets for connecting symbolic and visual representations of 3D vector equa-tions", Teaching Mathematics and Its Applications, vol. 33, no. 1, pp. 52-64, 2014. https://doi.org/10.1093/ teamat/hru005 
[41] E. Suherman., Turmudi, D Suryadi., T. Herman., Suhendra, S. Praba-wanto., Nurjanah, Rohayati, A, "Contemporary Learning Math Strategy," Bandung: JICA-UPI.

[42] S. J. Deny and M. K. Potts, "How Tutors Model Students: A Study of Per-sonal Constructs in Adaptive Tutoring," Am. Educ. Res. J., vol. 35, no. 1, pp. 65-99, 1998. https://doi.org/10.3102/00028312035001065

[43] J. Hardman, "Tutor-student interaction in seminar teaching: Implications for professional development," Act. Learn. High. Educ., vol. 17, no. 1, pp. 63-76, 2016. https://doi.org/10.1177/1469787415616728

[44] S. Ososky, S. Gilbert, B. Goldberg, and A. Sinatra, "The Future of Adap-tive Tutoring: Wrangling Complexity Across Domains, Applications, and Platforms," Proceedings of the Human Factors and Ergonomics Society 2017 Annual Meeting., pp. 1985-1989, 2017.

[45] T. W. Liew and S. Tan, "The Effects of Positive and Negative Mood on Cognition and Motivation in Multimedia Learning Environment," Educa-tional Technology \& Society, vol. 19, pp. 104-115, 2016.

[46] F. Rønning, "Influence of computer-aided assessment on ways of working with mathematics," Teach. Math. its Appl., vol. 36, no. 2, pp. 94-107, 2017. https://doi.org/10.1093/ teamat/hrx001

[47] G. D. Kinchin, understanding learning in Viv Ellis (Eds.), "Learning and Teaching in Secondary Schools". Southernhay East, UK: Learning Matters, pp. 30-34, 2007.

[48] S. Riaz, D. Rambli, R. Salleh, and A. Mushtaq, "Study to Investigate Learning Motivation Factors within Formal and Informal Learning Envi-ronments and their influence upon WebBased Learning," Int. J. Emerg. Technol. Learn., vol. 5, no. 4, pp. 1-10, 2010. https://doi.org/10.3991/ijet.v5i4.1338

[49] D.H. Schunk, P. R. Printrinch and J.L. Meece, "Motivation in education, theory, research, and application (3rd ed)". Trenton, New Jersey: Pearson Educational International, 2012.

[50] S. Ahmad, "Influence of math phobia, self-efficacy, adversity quotient and achievement motivation toward junior high school student achievement". Journal of Mathematics Education Research, vol. 3, no.2, pp. 259- 272.

[51] T. Y. Liu and Y. L. Chu, "Using ubiquitous games in an English listening and speaking course: Impact on learning outcomes and motivation". Com-puters \& Education, vol. 55, no 2, pp. 630-643, 2010. https://doi.org/10.1016/j.compedu.2010.02.023

[52] J. Sandberg, M. Maris and K. de Geus, "Mobile English learning: An Evi-dence-based study with fifth graders," Computers \& Education, vol. 57, no. 1, pp. 1334-1347, 2011. https://doi.org/10.1016/j.compedu.2011.01.015

[53] C. S. J. Huang, S. J. H. Yang, T. H. C. Chiang, and A. Y. S. Su, "Effects of Situated Mobile Learning Approach on Learning Motivation and Perfor-mance of EFL Students," Educ. Technol. Soc., vol. 19, no. 1, pp. 263-276, 2016.

[54] R. Donnelly, "Harmonizing technology with interaction in blended problem-based learning," Comput. Educ., vol. 54, no. 2, pp. 350-359, 2010. https://doi.org/10.1016/ j.compedu.2009.08.012

[55] S. Wichadee, "A development of the blended learning model using edmodo for maximizing students' oral proficiency and motivation," Int. J. Emerg. Technol. Learn., vol. 12, no. 2, pp. 137-154, 2017. https://doi.org/10.3991/ijet.v12i02.6324

[56] C. S. Chai, L. H. Wong, and R. B. King, "Surveying and modeling stu-dents' motivation and learning strategies for mobile-assisted seamless Chi-nese language learning," Educ. Technol. Soc., vol. 19, no. 3, pp. 170-180, 2016.

[57] Sugiyono, "Educational Research Methods Quantitative Approach, Qualita-tive, and R \& D". Bandung: Alfabeta, 2013. 
Paper-Development of Student Worksheet-Based College E-Learning Through Edmodo to Maximize ...

[58] J. McMillan and S. Schumacher, "Research in Education: A Conceptual In-troduction. 4th ed". New York: Longman, 1997.

[59] M. Finoccchiaro and C. Brumfit, "The Functional-Notional Approach: From Theory to Practice. 4th ed". Englewood Cliffs, NJ: Prentice Hall, 1983.

[60] E. T. Ruseffendi, "Fundamentals of Education Research and Other Non-Exact Areas". Bandung: Tarsito, 2009.

[61] M. Thongmak, "Social Network System in Classroom: Antecedents of Ed-modo (C Adoption," Journal of e-Learningand Higher Education, 2013.

[62] Ö. F. Ursavaş and I. Reisoglu, "The effects of cognitive style on Edmodo users' behaviour," Int. J. Inf. Learn. Technol., vol. 34, no. 1, pp. 31-50, 2017. https://doi.org/10.1108/IJILT06-2016-0019

[63] M. Alkhattabi, "Augmented Reality as E-learning Tool in Primary Schools' Education: Barriers to Teachers' Adoption," Int. J. Emerg. Technol. Learn., vol. 12, no. 2, pp. 91-100, 2017. https://doi.org/10.3991/ijet.v12i02.6158

[64] A. Gómez, Á. A. Magre-án, and L. Orcos, "UX of social network Edmodo in undergraduate engineering students," International Journal of Artificial Intelligence and Interactive Multimedia., vol. 3, no. 4, pp. 31-36, 2015. https://doi.org/10.9781/ijimai.2015.346

[65] S. C. Kong and Y. Song, "The Impact of a Principle-based Pedagogical De-sign on Inquirybased Learning in a Seamless Learning Environment in Hong Kong," Educational Technology \& Society., vol. 17, pp. 127-141, 2014.

\section{Authors}

Anton Nasrullah is lecturer education of mathematics, Bina Bangsa University, Indonesia (email: anton.nasrullah@binabangsa.ac.id).

Mira Marlina is lecturer education of mathematics, Bina Bangsa University, Indonesia, (email: mira.marlina@binabangsa.ac.id).

Widya Dwiyanti is lecturer education of mathematics, STKIP Sebelas April Sumedang, Indonesia, (email: widya_dwiyanti@stkip11april.ac.id).

Article submitted 29 March 2018. Resubmitted 15 and 22 August 2018. Final acceptance 23 August 2018. Final version published as submitted by the authors. 